\title{
CHLOROQUINE AND HYDROXYCHLOROQUINE: THE HISTORY REVISITED
}

\section{(Prof) Dr. Sujan Narayan Agrawal}

Department of Surgery, Late BRKM Government Medical College, Jagdalpur, P.O: JAGDALPUR. Bastar. (Chhattisgarh) PIN 494 001. India.

E-mail: drsujanagrawal@gmail.com; Mobile: 09406070087

ORCID ID: 0000-0001-5260-7865, Researchers ID: J-7304-2016

\section{Cite this article:}

Sujan N. Agrawal (2021), Chloroquine and Hydroxychloroquine: The History Revisited. African Journal of Biology and Medical Research 4(4), 1-7. DOI: $10.52589 / \mathrm{AJBMR}-$ XTOFIQY2.

\section{Manuscript History \\ Received: 2 Sept 2021 \\ Accepted: 22 Sept 2021 \\ Published: 27 Sept 2021}

Copyright $@ 2020$ The Author(s). This is an Open Access article distributed under the terms of Creative Commons AttributionNonCommercial-NoDerivatives 4.0 International (CC BY-NC-ND 4.0 ), which permits anyone to share, use, reproduce and redistribute in any medium, provided the original author and source are credited.

\begin{abstract}
The medicinal properties of the bark of the Cinchona tree have been known for centuries. It was known to cure fever and malaria. The active alkaloid was first isolated by the French chemists Pelletier and Coventou in 1820. The organized use of a large amount of quinine to prevent and treat malaria was largely done by the colonial military units in the tropics, especially in Africa and Southeast Asia. Scientists soon learned to synthesize quinine-like compounds which included chloroquine and hydroxychloroquine. Quinine (C18H26CIN3) was first synthesized successfully in 1934. In 1946, hydroxychloroquine (C18H26CIN3O) was developed as its less toxic alternative. Quinine derivatives, $C Q$ and $H C Q$, are weak bases chemically. They are accumulated in acidic food vacuoles of intraerythrocytic trophozoites. Its antimalarial action is due to the induction of selective toxicity to lysosomes in parasites, thereby preventing hemoglobin degradation. For a long time, the role of $C Q$ as an anti-inflammatory agent has been investigated. It is used as a disease-modifying agent against rheumatoid arthritis (RA) and systemic lupus erythematosus (SLE). It has antitumor activities also and has been studied in glioblastoma, colon, and pancreatic cancers. In the recent outbreak of the corona pandemic, there is a resurgence of interest in its use as an antiviral agent. Its mechanism of action is not fully understood; it may involve multiple pathways to act as an antiviral agent. The research activities to explore its efficacy and new applications in various diseases have never ceased. Despite its long history the drug and its derivatives have attracted scientists world-wide.
\end{abstract}

KEYWORDS: Cinchona Tree, Malaria, Quinine, Chloroquine, Hydroxychloroquine 


\section{INTRODUCTION}

It was known for centuries that the bark of the Cinchona tree (Cinchona spp., Rubiaceae) has medicinal properties to treat fever and malaria. [1] The therapeutic application of this natural product originated in South America. They later on made their way to European countries. In World War II, Europeans lost access to major Cinchona tree plantations in Java. [2] Alkaline extract of the cinchona bark from Andean forests was first recognized to treat a tropical fever when it was used in the countess of Chinchon in Peru. The Cinchona bark was used to suppress malaria in the soldiers as early as 1717 in the siege of Belgrade or battle of Belgrade. [3] James Lind of the British Royal Navy in 1777 recommended that ships on the Guinea station (West Africa) "be supplied with a large quantity of bark in powder and of wine to be issued occasionally to be sent in boats up rivers and on shore." [4] There was a great variation in the concentration of alkaloids in the cinchona bark. So, the active alkaloid was first isolated by the French chemists Pelletier and Coventou in 1820 with good accuracy. The organized use of a large amount of quinine to prevent and treat malaria was largely done by the colonial military units in the tropics, especially in Africa and Southeast Asia. [5-7] The voluminous body of historical literature is available which discusses the various aspects of the use of chloroquine for malaria prevention and black water fever. [8-10] Scientists soon learned to synthesize quinine-like compounds which included chloroquine and hydroxychloroquine. [11]

The study of the cinchona bark and its extract is a key event in the history of medicinal chemistry. The pure compound was extracted in 1820 by Coventou and Pelletier. The quinine itself was not synthesized until 1944. There has never been a synthesized product that can compete with the extract from the bark. It was a time when whatever cured malaria should be understood not just as a medicine but also as a military weapon. Malaria was known to kill more soldiers than bullets during the war. So, finding a cure for malaria was seen as a tool of the empire. It was not known how the bark of the cinchona plant helped to fight malaria until two French scientists discovered the chemical found in the plant i.e., quinine. It took centuries to find a synthetic version of quinine so as not to remain dependent on the plant source.

\section{Chloroquine (CQ) and Hydroxychloroquine (HCQ):}

Paul Ehrlich in 1891 found that the synthetic dye Methylene blue has antimalarial properties. It is selectively absorbed by malaria parasites. The problem was that the dose required as antimalarial was huge. Pamaquine was synthesized in 1925 by replacing one methyl group with a basic side chain; it has also improved its antimalarial activities. From this, quinacrine was derived which is an acridine derivative of it. Then two chloroquine analogues were developed, Sontoquine and primaquine; then, chloroquine was derived from it. [12-13]

Quinine (C18H26CIN3) was first synthesized successfully in 1934. In 1946, hydroxychloroquine $(\mathrm{C} 18 \mathrm{H} 26 \mathrm{CIN} 3 \mathrm{O})$ was developed as its less toxic alternative. These are used as the primary drug for the treatment of malaria. Their use for malaria has reduced in the past decade due to increasing resistance. [14] Quinine derivatives, CQ and HCQ, are weak bases chemically. They are accumulated in acidic food vacuoles of intraerythrocytic trophozoites. Its antimalarial action is due to the induction of selective toxicity to lysosomes in parasites, thereby preventing hemoglobin degradation. [15] Because of increasing resistance, CQ is rarely used nowadays to treat malaria caused by plasmodium falciparum. [16] It is still effective for the malaria fever caused by Plasmodium ovale, Plasmodium malariae and Plasmodium vivax in most parts of the world. [17-18] 


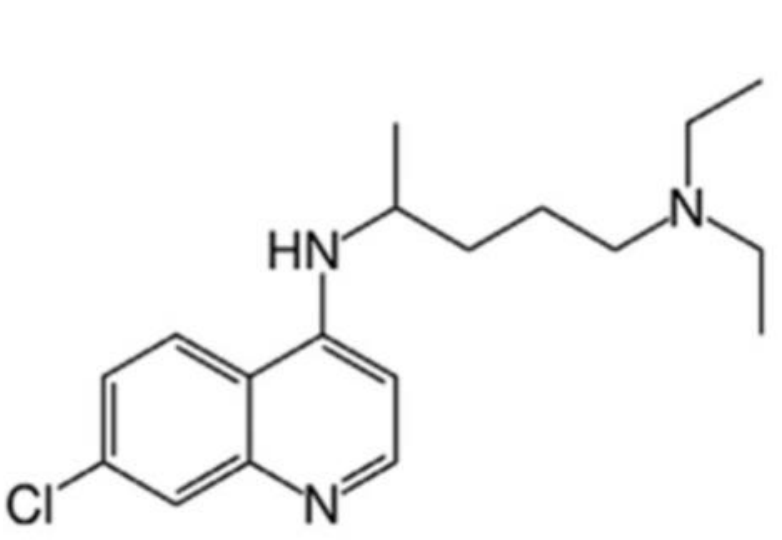

Chloroquine (CQ)

CAS number: 54-05-7

Formula: $\mathrm{C}_{18} \mathrm{H}_{26} \mathrm{CIN}_{3}$

Mol.mass: $319.872 \mathrm{~g} / \mathrm{mol}$

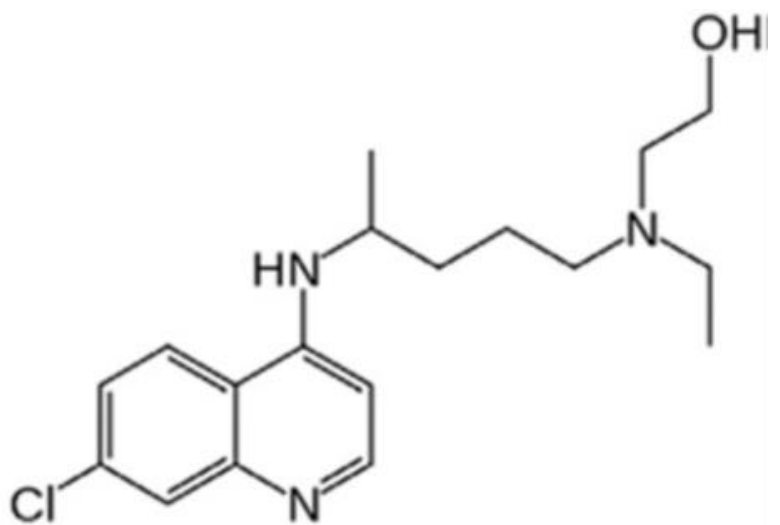

Hydroxychloroquine (HCQ)

CAS number: $118-42-3$

Formula: $\mathrm{C}_{13} \mathrm{H}_{26} \mathrm{CIN}_{3} \mathrm{O}$

Mol.mass: $335.872 \mathrm{~g} / \mathrm{mol}$

\section{Figure: Molecular structures of 4-aminoquinolines: chloroquine and hydroxychloroquine. [19-20]}

In India too, there is an interesting story related to the defeat of King Tipu Sultan in Mysore. Sultan was defeated by the British in 1799. The Mysore kingdom along with its capital Srirangapatna came under British control. British soldiers celebrated the victory, but within a few days, they started falling sick due to malaria. Srirangapatna was a highly marshy area with a dense mosquito population. The locals have some immunity due to repeated mosquito bites but the British soldiers had a tough time fighting malaria. As a strategic measure, the British army shifted its base from Srirangapatna to Bangalore, and thus the Bangalore cantonment region came into existence. But the malaria problem still existed since Bangalore was no exception as far as mosquitos and malaria were concerned. It was a time in the 18th century when European scientists discovered the chemical composition of quinine and its use against malaria. The British army imported this compound in bulk and distributed it among their soldiers. They were instructed to take a regular dose of this drug. This became a practice in all other British army stations throughout India. The bitter taste was a great hindrance to regular compliance with drug intake. To mask the bitter taste, it was mixed with gin, and the mixture was called "gin and tonic". It became an instant hit since not only did it mask the bitter taste, it gave it a sweeter taste, and it was issued as a monthly ration to the soldiers. To meet the demand for gin, several breweries were established in and around Bangalore. Over the years, quinine was developed further into many of its variants and derivatives and was widely prescribed by doctors. One such descendant of quinine is hydroxychloroquine. During the corona pandemic, it became the most sought-after drug. [21] 


\section{CQ and HCQ pharmacological activities:}

\section{Antimalarial Activity}

The CQ and HCQ were developed as antimalarials. This action is due to their selective toxicity to lysosomes which prevents hemoglobin degradation. [22]

\section{Anti-Inflammatory Activity}

For a long time, the role of CQ as an anti-inflammatory agent has been investigated. It is used as a disease-modifying agent for rheumatoid arthritis (RA) and systemic lupus erythematosus (SLE). It is also being evaluated for other inflammatory conditions like Sjogren's syndrome, antiphospholipid syndrome, inflammatory bowel disorders (IBD), etc. [23] It inhibits autophagy and prevents activation of major histocompatibility complexes, besides the disruption of lysosomal enzyme activities.

\section{Antitumor Activity}

Its antitumor activities have been extensively studied in glioblastoma (GBM), colon, and pancreatic cancers. Its activities are more pronounced for its synergistic effects along with other antitumor agents. [24-26]

\section{Antiviral Activity}

CQ and its derivatives are evaluated for various viral infections.[27] They have shown antiviral activities against many viral infections like Zika virus, HIV and Hepatitis $\mathrm{C}$ virus, etc. Their mechanism of action is not fully understood. It might involve multiple pathways. It may be because of blockage of endosomal mediated viral entry. They also exhibit anti-inflammatory and immunomodulatory properties. [28] During this coronavirus disease 2019 (COVID-19) pandemic, this drug has shown to compromise the binding affinity of S protein on Severe Acute Respiratory Syndrome Coronavirus (SARS-CoV-2) to the gangliosides of the host's cell surface. [29] Currently, the National Institutes of Health recommends neither for nor against CQ /HCQ as a treatment for COVID-19. [30] Moreover, the organization does not support the HCQ or HCQ+ Azithromycin combination due to its potential toxicity. Getting a result from well-designed RTCs to assess the efficacy and safety of CQ or HCQ for or against infection by SARS-CoV-2 is the call of the times.

\section{Adverse effect and toxicity:}

It has been observed that $\mathrm{CQ} / \mathrm{HCQ}$ use can impede the conduction in sodium and potassium channels, which leads to ST-segment depression and QT interval prolongation. It can also cause a complete atrioventricular block. [31-32] This cardiotoxicity was observed with acute overdose as well as chronic use of $\mathrm{CQ} / \mathrm{HCQ}$. Its chronic use has been reported to cause irreversible damage to retinal function. [33] 


\section{CONCLUSION}

The medicinal properties of the active compound in the cinchona bark, the Quinine, had long been known to the natives of South America when it was used for malaria. The study of cinchona bark and its extract is a key point in the history of medicine and pharmacology. The pure chemical was extracted in 1820 by Coventou and Pelletier. In 1891, Paul Ehrlich found that Methylene blue, a synthetic dye, has antimalarial properties. The chloroquine was first synthesized in 1934 by Hans Andersag at Bayer's laboratory. It was the first major antimalaria drug after World War II; it was discovered to have a strong antimalarial activity. Hydroxychloroquine came in 1950 by having one extra $\mathrm{OH}$ group. The exact mechanism of its action against malaria parasites is still not very clear. It might have several modes of action. It is also used as a disease-modifying agent against Rheumatoid arthritis and SLE; again the mechanism of action is ill-understood. It has been found to have antiviral and antitumor activities also. History indicates what is needed in the future, without undergoing the pains and failures of the past. The medicines which are difficult to administer or which have multiple side effects are not a good choice to be given to an otherwise well person as prophylaxis. When the benefits of the medicine are only the absence of disease in the future, the perceived risk needs to be very low. It is hoped that future medications for malaria chemoprophylaxis will provide a substantial improvement from the present scenario.

\section{Declarations}

Funding: None.

Conflict of Interest: None declared.

Ethical approval: Not required.

\section{REFERENCES}

[1] Achan J, Talisuna AO, Erhart A, et al (2011). Quinine, an old anti-malarial drug in a modern world: role in the treatment of malaria. Malar J. 10(1):144. doi: 10. 1186/ 1475- 2875- 10- 144

[2] Bruce-Chwatt L J., (1988). Three hundred and fifty years of the Peruvian fever bark. $\mathrm{Br}$ Med J. 296(6635):1486-1487. doi: 10. 1136/bmj. 296. 6635. 1486

[3] Sappington J, (1844). The Theory and Treatment of Fevers. St Louis, MO: J. Sappington.

[4] Brown WC, (1911). The present position of the quinine prophylaxis of malaria. Trans $\mathrm{R}$ Soc Trop Med Hyg 4: 193-209.

[5] Christophers S, Shortt H, (1921). Incidence of malaria among troops in Mesopotamia, 1916-1919. Indian J Med Res 8: 553-570.

[6] Wenyon CM, Anderson A, McLay K, Hele T, Waterston J, (1921). Malaria in Macedonia, 1915-1919. J R Army Med Corps 37:81-82.

[7] Bruce-Chwatt L J, (1985). John Hull Grundy lecture. Mosquitoes, malaria and war; then and now. J R Army Med Corps 131:85-99.

[8] Ross R, (1897). On some peculiar pigmented cells found in two mosquitos fed on malarial blood. BMJ 2: 1786.

[9] James SP, (1903). Report of the Anti-Malarial Operations at Mian Mir, 1901-1903. Calcutta, India: Office of the Superintendent of Government Printing. 
[10] Christophers SR, 1904. Second Report of the Anti-Malarial Operations at Mian Mir, 1901-1903. Calcutta, India: Office of the Superintendent of Government Printing, India.

[11] Al-Bari MAA. (2015). Chloroquine analogues in drug discovery: new directions of uses, mechanisms of actions and toxic manifestations from malaria to multifarious diseases. $J$ Antimicrob Chemother. 70(6):1608-1621. doi: 10. 1093/ jac/ dkv018

[12] Rodriguez-Caruncho C, Bielsa Marsol I (2014). Antimalarials in dermatology: mechanism of action, indications, and side effects. Actas Dermosifiliogr 105: 243-52.

[13] Chen C. (2014). Development of antimalarial drugs and their application in China: historical review. Infect Dis Poverty 3: 9.

[14] White NJ (1996). The treatment of malaria. N Engl J Med. 335(11):800-806. doi: 10. 1056/ NEJM 199609123351107

[15] Slater AF, (1993). Chloroquine: mechanism of drug action and resistance in Plasmodium falciparum. Pharmacol Ther. 57(2-3): 203-235.doi: 10. 1016/ 0163-7258(93) 90056-J

[16] Plewes K, Leopold SJ, Kingston HWF, Dondorp AM, (2019). Malaria: what's new in the management of malaria? Infect Dis Clin North Am. 33(1):39-60. doi: 10. 1016/ j. idc. 2018. 10. 002

[17] Prevention C-C for DC and. CDC - malaria - travelers - malaria information and prophylaxis, by country.

[18] Plewes K, Leopold SJ, Kingston HWF, Dondorp AM, (1019). Malaria: what's new in the management of malaria? Infect Dis Clin North Am. 33(1):39-60. doi: 10. 1016/ j. idc. 2018. 10. 002

[19] Xu C, Zhu L, Chan T, et al., (2016). Chloroquine and hydroxychloroquine are novel inhibitors of human organic anion transporting polypeptide 1A2. J Pharm Sci. 105(2):884-890. doi: 10. 1002/jps. 24663

[20] Yang Song, Elise Fields. Pharmacological Advances of Chloroquine and Hydroxychloroquine: From Antimalarials to Investigative Therapies in COVID-19. Natural Product Communications Volume 15(9): 1-7. DOI: 10. 1177/ 1934 578X 20953648

[21] https://greatgameindia.com/the-history-of-Hydroxychloroquine-in-india/ accessed on 01.09.2021

[22] Slater AF, (1993).Chloroquine: mechanism of drug action and resistance in Plasmodium falciparum. Pharmacol Ther. 57(2-3):203-235. doi: 10. 1016/ 0163- 7258( 93) 90056-J

[23] Plantone D, Koudriavtseva T, (2018).Current and future use of chloroquine and hydroxychloroquine in infectious, immune, neoplastic, and neurological diseases: a mini-review. Clin Drug Investig. 38(8):653-671. doi: 10. 1007/ s40261- 018- 0656-y

[24] Molejon MI, Swayden M, Fanale D, et al., (2018) Chloroquine plays a cell-dependent role in the response to treatment of pancreatic adenocarcinoma. Oncotarget. 9(56):30837-30846. doi: 10.

18632/ onco target. 25745

[25] Verbaanderd C, Maes H, Schaaf MB, et al, (2017). Repurposing Drugs in Oncology (ReDO)-chloroquine and hydroxychloroquine as anti-cancer agents. Ecancermedicalscience. 11:781 doi: 10. 3332/ecancer. 2017. 781

[26] Varisli L, Cen O, Vlahopoulos S.,(2020) Dissecting pharmacological effects of chloroquine in cancer treatment: 6 Natural Product Communications interference with inflammatory signaling pathways. Immunology. 159(3):257-278. doi: 10. 1111/ imm. 13160 
[27] D'Alessandro S, Scaccabarozzi D, Signorini L, et al., (2020). The use of antimalarial drugs against viral infection. Microorganisms. 8(1):5-10. doi: 10. 3390/ micr oorg anis ms80 10085

[28] Al-Bari MAA., (2017). Targeting endosomal acidification by chloroquine analogues as a promising strategy for the treatment of emerging viral diseases. Pharmacol Res Perspect. 5(1):e00293 doi: 10.1002/ prp2. 293

[29] Fantini J, Di Scala C, Chahinian H, Yahi N., (2020). Structural and molecular modelling studies reveal a new mechanism of action of chloroquine and hydroxychloroquine against SARS-CoV-2 infection. Int J Antimicrob Agents. 55(5):105960 doi: 10. 1016/ j. ijan timicag.2020. 105960

[30] The National Institutes of Health (NIH). COVID-19 Treatment Guidelines. Published April 2020. April 24, 2020. https://www.covi d19 treatment guidelines. nih. gov/ introduction/

[31] Tonnesmann E, Kandolf R, Lewalter T., (2013). Chloroquine cardiomyopathy -a review of the literature. Immunopharmacol Immunotoxicol. 35(3):434-442. doi: 10. 3109/ 08923973. 2013. 780078

[32] Jordan P, Brookes JG, Nikolic G, Le Couteur DG., (1999). Hydroxychloroquine overdose: toxicokinetics and management. J Toxicol Clin Toxicol. 37(7):861-864. doi: 10. 1081/ CLT- 100102466

[33] Yusuf IH, Sharma S, Luqmani R, Downes SM., (2017). Hydroxychloroquine retinopathy. Eye.31(6): 828-845. doi: 10. 1038/ eye.2016. 298 